\title{
Entrepreneurship and Equity Crowdfunding: Does It Matter?
}

\author{
Ciro Troise ${ }^{1}$ \\ ${ }^{1}$ Department of Management, Università degli Studi della Campania "Luigi Vanvitelli”, Capua (CE), Italy \\ Correspondence: Ciro Troise, Department of Management, Università degli Studi della Campania "Luigi \\ Vanvitelli”, Corso Gran Priorato di Malta - 81043 Capua (CE), Italy. E-mail: ciro.troise@unicampania.it
}

Received: August 4, 2019

doi:10.5539/ijbm.v14n10p72
Accepted: August 26, 2019

Online Published: September 5, 2019

URL: https://doi.org/10.5539/ijbm.v14n10p72

\begin{abstract}
This study aims to explore how entrepreneurship, i.e. the three well-known dimensions of entrepreneurial orientation (EO) (innovativeness, risk taking and proactiveness), affects equity crowdfunding (ECF) performance. Many contributions in the entrepreneurship literature suggested that the entrepreneurial process is incomplete with the creation of a new venture. In this vein, the present paper focuses on the company's fundraising capability, a stage that follow the establishment of a new business. Empirical regression analyses were performed and the sample consists of 134 projects collected from seven Italian platforms. Interesting successful drivers, belonging to the EO sphere, emerge from the study. Findings show statistically significant influence of the three exploratory variables: product innovation (as expression of innovativeness) and planning (as expression of proactiveness) positively affect ECF performance, while equity offered (as expression of risk taking propensity) has a negative impact. Scholars have little knowledge about the role of entrepreneurship in the ECF context, this study sheds some light on the importance of entrepreneurial aspects. The originality of this study lies both in the entrepreneurial framework and in the factors analyzed. The insights could have interesting implications for entrepreneurs, platform managers, investors and policy makers.
\end{abstract}

Keywords: entrepreneurship, entrepreneurial orientation, entrepreneurial process, crowdfunding, performance

\section{Introduction}

In recent decades, there has been a significant diffusion of entrepreneurship and in fact this era is defined as the 'entrepreneurial age' (Bygrave, 2004). Over the last years, interest among academicians in entrepreneurial issues has grown. In particular, scholars studying entrepreneurship are increasingly interested in the entrepreneurship processes (Leyden \& Link, 2015; Moroz \& Hindle, 2012).

Historically, the entrepreneurship literature identified the creation of a new business as the final stage of the entrepreneurial process (Kessler \& Frank, 2009; Korunka et al., 2003; Reynolds, 2007). Despite the strong focus on new venture creation, a growing number of scholars embrace the idea that the entrepreneurial process does not end with the establishment of the company (Brockner et al., 2004; Cardon et al., 2005; DeTienne, 2010; Shane \& Venkataraman, 2000). In this new research stream of entrepreneurship, many studies supported the importance of the post-creation lives of new ventures and that the entrepreneurial process continues after establishing a new venture. Based on this perspective, a number of scholars suggested that the entrepreneurial process is not complete without considering the future phases following the creation of the new venture, such as the entrepreneurial exit (DeTienne, 2010), the opportunity identification (Shane \& Venkataraman, 2000), company growth or procuring resources (Brockner et al., 2004; Cardon et al., 2005).

Following these perspectives based on the continuity of the entrepreneurial process, the present study focuses on the companies' capabilities to raise funds. More precisely, this work considers a specific stage that follows new venture creation, i.e. the fundraising. For new companies, it is vital to identify and procure the necessary sources of funding to pursue new opportunities (Carter et al., 1996; Cunneen \& Mankelow, 2007; Kortum \& Lerner, 2000; Shane \& Cable, 2002).

In the last few years, scholars are more and more attracted by new forms of fundraising. Among the new mechanism for financing entrepreneurship, equity crowdfunding (hereafter ECF) has emerged as a concrete and popular system for entrepreneurs (Vulkan et al., 2016). In line with prior scholars who suggested 'equity crowdfunding is the most empirically relevant for studying entrepreneurial signalling to small investors' (Ahlers, et al., 2015, p. 957), also this paper acknowledge the importance of examining ECF. 
ECF platforms allow entrepreneurs to collect financing resources for their initiatives from the crowd, typically small and not sophisticated investors (Belleflamme et al., 2014) that differ from traditional players (e.g. venture capitalists and angel investors). Although ECF has a rapid growth, not all campaigns are successful and many companies do not get financing due to non-achievement of the funding goal (Ahlers et al., 2015; Lukkarinen et al., 2016; Vismara, 2016). An important feature of ECF campaigns is the strong presence of information asymmetries between entrepreneurs and investors. These asymmetries act as barriers between the two parties involved in the ECF process and represent an obstacle to the success of the projects launched on platforms. In order to mitigate the problem of information asymmetry, entrepreneurs can send signals to investors (Spence, 1973).

Recently, some scholars adopted this new perspective and leveraged signalling theory (Ahlers et al., 2015; Block et al., 2018; Hornuf \& Schwienbacher, 2018; Lukkarinen et al., 2016; Polzin et al., 2018; Ralcheva \& Roosenboom, 2016; Vismara, 2016; Vulkan et al., 2016). Even if the number of papers that explore success drivers of campaigns is increasing (Mochkabadi \& Volkmann, 2018), there is a lack of empirical studies that analyze entrepreneurial aspects of the companies as signals in the ECF context.

This paper aims at contributing to fill this gap, namely the shortage of studies that address the issue of information asymmetries in ECF through signals derived from the entrepreneurial skills of the company. Moving from this aim, this paper recalls the well-known concept of entrepreneurial orientation (hereafter EO) (Covin \& Slevin, 1989, 1991; Lumpkin \& Dess, 1996; Miller, 1983) and concentrates its attention on three commonly used variables in the entrepreneurship literature - i.e. product innovation, equity offered and planning - as potential signals that could explain the success of ECF campaigns. These typical entrepreneurial parameters are respectively expressions of the three traditional EO dimensions: innovativeness, risk taking and proactiveness.

Put simply, this contribution proposes that the above cited entrepreneurial aspects could influence ECF performance outcomes, i.e. funding amount and number of investors. The study conducts regression analyses on 134 projects and it intends to explore the Italian ECF context. Italy is a pioneer country in regulating ECF (Vismara, 2016) and - in fact - implemented an ad hoc regulation (D.L. 179/2012).

The contribution proposes an original entrepreneurial framework for studying success signals and provides empirical evidence of new factors related to the entrepreneurship sphere in a developed country in theme of ECF. This paper attempts to contribute to the current entrepreneurship literature.

The paper is organized as follows. The next section presents the theoretical background and research hypotheses. The third section describes the data and the methodology. The results are presented in the fourth section, while the last section contains discussions and conclusions, including limits and implications for both practitioners and scholars.

\section{Theoretical Background}

It is well known that the information asymmetries between two actors - in this specific case entrepreneurs and investors - can lead to the risk of adverse selection and potential market failure (Akerlof, 1970). In the virtual environment of online platforms, the risk of financing a potentially bad project (a 'lemon') for investors is high. The well-known 'lemons problem' (Akerlof, 1970) refers to issues that arise due to asymmetric information held by investors and entrepreneurs which refers to the value of the company. In this scenario, the separation between high quality and low quality projects is difficult to recognize. Furthermore, a relevant issue is moral hazard due to possible opportunistic actions by entrepreneurs. They have more knowledge of the quality underlying the initiative and have information about the venture that they might not reveal to investors.

Investors have limited knowledge to evaluate investments and should face high due-diligence costs (Ahlers et al., 2015). Moreover, the lack of signals deriving from the reputation of the endorsers (professional intermediaries such as banks) increase the potential risks for investors. Entrepreneurs face the issue of communicating useful information about their company. This problem takes on greater significance in new ventures that have little track record and present higher uncertainty about their future development or profitability.

According to the signalling theory (Spence, 1973), observable signals could mitigate the information asymmetries, to the extent that they can show the quality and value of the venture. On the one hand, credible information could increase investors' knowledge of the company (thus their ability to decode signals), on the other hand, these signals could help entrepreneurs achieve superior ECF performance. Thus, signals could play a key role in improving ECF outcomes, but - as Ahlers et al. (2015) suggested - not all the information on the quality of a company are effectively signals to mitigate asymmetries.

This study, taking into account the previous studies in literature, considers three factors of the entrepreneurial 
sphere (product innovation, equity offered and planning) as potential effective signals for investors. To the knowledge of the author, there are no discussions on EO in the ECF field and there is a lack of studies that consider the role of EO dimensions in the success of ECF campaigns.

In the recent crowdfunding literature, only a prior paper by Oo et al. (2018) explored entrepreneurship as a signal, even though it focused on the reward crowdfunding model. The scholars highlighted that entrepreneurship serves as a signal of capability and commitment to potential investors. The present work leverages the signalling theory and tries to add new knowledge on ECF performance by focusing on new entrepreneurial signals.

Figure 1 shows the entrepreneurial framework - with related hypotheses - that describes the relationship between the independent variables and ECF performance.

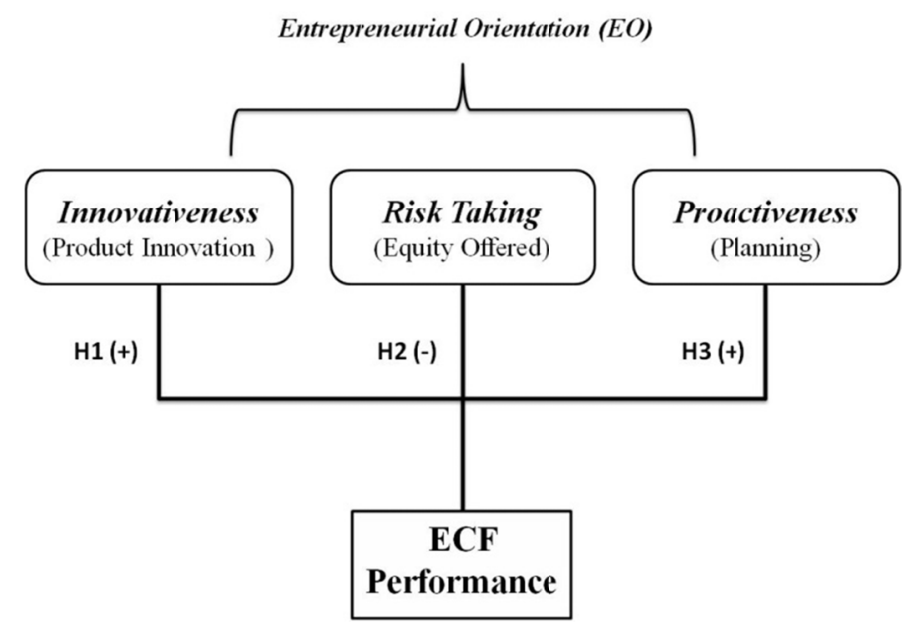

Figure 1. Entrepreneurial Framework

Source: Author's own.

\subsection{Research Hypotheses}

Entrepreneurship is often considered as a multidimensional concept in the literature. The studies that extended the concept of entrepreneurship from individual level to organizational level, mainly focused on innovativeness (Cooper, 1973), risk taking (Kets de Vries, 1977) and proactiveness (Miller \& Friesen, 1978). Historically, these three dimensions give rise to the concept of EO (Covin \& Slevin, 1989, 1991; Lumpkin \& Dess, 1996; Miller, 1983). EO represents a critical factor for venture performance (Covin \& Slevin, 1989, 1991; Lumpkin \& Dess, 1996) and is also considered an expression of the entrepreneurial firms (Miller, 1983).

Several academicians considered subjective measures within the EO construct and used different variables as expressions of the single dimensions (Fernández-Serrano \& Romero, 2013; Guzmán \& Santos, 2001; Santos-Cumplido \& Liñán, 2007; Stevenson \& Jarillo, 1990; Wiklund, 1999; Zahra, 1991).

Starting from the pre-existing literature on EO, this study examines the three traditional dimensions established in literature within the EO construct and adopts specific variables - contextualizing some aspects to the ECF context - for each dimension. Precisely the work considers three significant parameters to express entrepreneurship through the concept of EO: product innovation as expression of innovativeness; equity offered as expression of risk taking propensity; planning as expression of proactiveness.

\subsubsection{Product Innovation (Innovativeness)}

Innovativeness refers to a company's propensity to engage in a new idea generation, novelty, experimentation and creative activities resulting in new products/services (Lumpkin \& Dess, 1996). In this vein, many academicians suggested that innovation is represented by the introduction of a new product/service characterized by novelty - thus not yet familiar to consumers - or a new quality (Covin \& Miles, 1999; Schumpeter, 1947; Zirger \& Maidique, 1990). These new products/services create a new market niche or penetrate established markets (Lee et al., 2001; Lumpkin \& Dess, 1996; Miller \& Friesen, 1982).

Historically, product innovation is one of the most widely used proxy of innovativeness. In fact, much 
entrepreneurship literature related to EO sphere recurred to product innovation within the innovativeness dimension (Fernández-Serrano \& Romero, 2013; Lee et al., 2001; Lumpkin \& Dess, 1996; Miller, 1983; Santos-Cumplido \& Liñán, 2007). This parameter is a critical strategy for companies (Eisenhardt \& Schoonhoven, 1990; Li \& Atuahene-Gima, 2001; McCann, 1991), in particular for new ventures, and a number of scholars analysed it as a dimension of the entrepreneurial strategic posture of companies (Covin \& Slevin, 1989; Miller, 1987; Zahra \& Covin, 1993). Product innovation is also a significant element for increase the competitiveness of the companies (Bruton \& Rubanik, 2002; Chen et al., 2004; Huang \& Liu, 2005).

Investors have always appreciated the innovative capability of new ventures (Baum \& Silverman, 2004). This is even more evident for equity investors (Kortum \& Lerner, 2000). In the crowdfunding research stream, Oo et al. (2018) highlighted that investors are more likely to fund the development of higher innovation products, contrariwise to lower innovation products. Investors, in crowdfunding contexts, typically finance campaigns in order to support entrepreneurs to bring their initiatives to market and be successful (Cholakova \& Clarysse, 2015; Ordanini et al., 2011). Therefore, investors could commit financial resources in a company that plan to create new innovative products if they are indeed convinced of their success and profitability. Furthermore, investors could have interest in some specific products/services. In some cases, entrepreneurs could offer future products/services to investors in addition to equity shares.

Companies, especially young and innovative, can send signals to investors about their initiative's quality through actions to introduce new innovative products (Deeds et al., 1997; Nadeau, 2010; Smith et al., 2005). These signalling actions represent significant indicators of the company's prospects and competence. In ECF campaigns, entrepreneurs can show if their company intends to create or launch new products/services for their customers. This information could represent a signal of the innovative efforts of the firm and it is reasonable to assume that a positive effect will emerge on ECF performance outcomes. Based on this, campaigns could have more investors and even more funds. This study proposes that crowdfunding investors will be more likely to fund the development of product innovations. Thus, the following hypothesis is provided.

\section{Hypothesis 1: Product innovation positively affects ECF performance.}

\subsubsection{Equity Offered (Risk Taking)}

As Lumpkin \& Dess (1996, p. 144) observed, 'risk has various meanings, depending on the context in which it is applied'. Companies with an entrepreneurial orientation are often typified by risk-taking behaviour, such as risky resource commitments (Baird \& Thomas, 1985; Miller \& Friesen, 1978).

According to Leland and Pyle (1977), a quality signal of the initiative is represented by the entrepreneur's equity retention. If the entrepreneur is indeed convinced of the company's potential, he will invest in it holding more equity shares. Contrariwise, entrepreneurs will offer higher equity shares to investors if they have a lower commitment in the company or they do not expect profits (future cash flows higher than current firm value). Also in studies on IPOs and VCs (Busenitz et al., 2005), equity retention represents a positive signal.

Engage in risky projects highlights the propensity to take risks by entrepreneurs. A close equity retention reflects a low risk taking propensity. Future returns from projects are uncertain, so entrepreneurs sell a large equity proportion if they do not intend to take risks and prefer to monetize the current value of the company from the sale (with a dilution effect).

Starting from the previous contributions in the ECF field, this work analyses the equity offered as the percentage of equity shares that the company makes available to new investors (Ahlers et al., 2015; Ralcheva \& Roosenboom, 2016; Vismara, 2016). The amount of equity offered in the ECF campaign is a signal that allows investors to know the level of the shares that the entrepreneurs retain. This information represents also a signal of the commitment of the entrepreneur (Vismara, 2016) and of the value of the company (Ahlers et al., 2015).

In the ECF context, the likelihood of investing money in a project decreases with an increase of the uncertainty level (Ahlers et al., 2015). In this vein, equity retention represents a significant quality signal (Vismara, 2016) able to reduce uncertainty for investors. Therefore, it is possible to argue that - other things being equal - the likelihood of success of the campaign is reduced when larger equity shares are offered. This is because the entrepreneur retains much equity in a good company and less in the opposite case, signalling in this way the companies' value.

In this case, equity offered - a typical information about the willingness of entrepreneurs to invest in their own project - is used as an expression of the risk taking propensity. Thus, the following hypothesis is developed.

Hypothesis 2: Equity offered in large percentage negatively affects ECF performance. 


\subsubsection{Planning (Proactiveness)}

Planning can be considered a typical parameter that identifies proactiveness. This variable has been adopted as a measure of proactivity by several scholars (Fernández-Serrano \& Romero, 2013; Guzmán \& Santos, 2001; Lepak et al., 2005; Santos-Cumplido \& Liñán, 2007). It represents a dynamic initiative to energize the business and a strategic behaviour of entrepreneurs (Lumpkin \& Dess, 1996).

Scholars tried to measure proactiveness through some behaviours, such as seeking money to invest, investing in the training of employees, putting into practice long-term planning of activities, realising plans for growth, creating new products/services, developing technological innovation or searching for new markets and sources of supply (Guzmán \& Santos, 2001; Santos-Cumplido \& Liñán, 2007). For companies, the lack of initiative to plan and of a long-term view are not related to proactiveness. The study of Fernández-Serrano \& Romero (2013, p. 498), reported that 'among the characteristic activities of proactive entrepreneurs, business planning has been pointed out as a strategic policy facilitating firm growth'.

Planning is considered a strategic driver for company development (Fernández-Serrano \& Romero, 2013) and the literature identified it as one of the most important factors that determine venture success (Block \& MacMillan, 1985; Quinn, 1979; Vesper \& Holmdahl, 1973). Following these contributions, this study supports the importance of planning also in the ECF context. In this study, in fact, planning activities and efforts are considered as factors related to ECF performance.

In the ECF context is important to exhibit long-term planning activities because this could affect the decision-making process of potential investors and limit information asymmetries related to the development of the company. In this way, entrepreneurs could induce a higher number of investors to commit more financial resources. Therefore, it is possible to argue that planning can be a success determinant of crowdfunding projects. In fact, the absence of a planning activity and proactive initiatives can be seen as a form of 'passiveness' (Lumpkin \& Dess, 1996) of the company. This is in contrast with the company's proactivity, therefore investors may decide not to invest in it, given the risks and uncertainty about the future. In this respect, the following hypothesis is proposed.

Hypothesis 3: Planning activities positively affect ECF performance.

\section{Research Design}

\subsection{Data and Variables}

\subsubsection{Sample}

The empirical analyses use data from seven Italian ECF platforms - i.e. CrowdFundMe, Backtowork24, Mamacrowd, Muumlab, Nextequity, StarsUp, 200crowd - over the period from January 2014 to June 2018. The sampling period covers all the campaigns launched on the portals since their origin. These platforms together represent about $75 \%$ of the overall ECF market in terms of funding obtained and about $70 \%$ of the total number of campaigns launched in Italy (Politecnico, 2018).The initial sample consisted of 137 projects, but three of them are outliers and show values over $600 \%$. Thus, the final sample presents 134 initiatives and includes both successful projects (that reach the target of $100 \%$ or super it in overfunding) and failed projects (that do not reach the target and have a percentage lower than 100\%).

Data collection was done through the online spaces of ECF portals where entrepreneurs provide information, documents (e.g. a business plan or a pitch) and links to social networks (e.g. Facebook, LinkedIn). Furthermore, the company websites and the official Business Register databases were analyzed. This last source is particularly useful for control variables (e.g. years, sector, location and type of company), while dependent variables and explanatory variables are mostly present on the online pages of campaigns. Campaigns show funding amount, number of investors and equity offered on the main page. About product innovation and planning, it was important to analyse also the attached documents and the descriptions of the initiatives in the different sections of the campaigns window and the pitches. Useful information was found on: ideas, new products/services, plans, strategy, use of funds, future actions or activities. Finally, a direct check was also made - through phone-based or web-based (e.g. LinkedIn, Skype and email) interviews - with platforms managers and entrepreneurs.

\subsubsection{Measurement of ECF performance}

ECF performance is measured as a dependent variable using the funding amount (Model 1) and number of investors (Model 2). These two parameters are the most commonly used indicators to measure ECF success in the current literature. In line with previous papers in this new research stream, this study considers the funding amount in percentage (Colombo et al., 2016; Ralcheva \& Roosenboom, 2016; Vismara, 2016, 2018; Zheng et al., 
2014). This choice takes into account the latest trends in crowdfunding literature, where this measure has recently been preferred over the dummy variable (equal to one if the project has reached the target) because it describes both the success rate ( 1 if it reached the $100 \%$ and more than 1 in case of overfunding) and the failure rate $(<1$, because the platforms work with the 'all or nothing' model) of projects. This measure is stronger (than the dummy) as it indicates how close the pitch was to reaching its target, in the case of failure projects, or how much the fundraising exceeds the target goal, in the case of successful projects (in this case measuring its overfunding rate).

Also the number of investors is a typical parameter to measure ECF performance and it has already been used as a dependent variable in several studies (Ahlers et al., 2015; Block et al., 2018; Lukkarinen et al., 2016; Ralcheva \& Roosenboom, 2016; Vismara, 2016). It indicates the final number of backers at the end of ECF campaigns. These people transferred funds and supported the initiative by investing in it. Since the logic of ECF is to involve the crowd and accumulate a large number of investors (Vismara, 2016), it is important to consider this variable as proxy of ECF success.

\subsubsection{Explanatory Variables}

In this study three explanatory variables are considered: Product Innovation, Equity Offered and Planning. These three parameters are respectively expression of three dimensions that belong to the well known EO construct: innovativeness, risk taking, proactiveness.

The first explanatory variable is Product Innovation. Since many companies have as their main object the production and commercialisation of innovative products or services, this variable included the creation and introduction of new products/services for their customers in the following years. If a company has planned these actions, shows their propensity to innovate and improve the offer for its customers (Guzmán \& Santos, 2001). This is an expression of the company' innovative capability. In this case a dummy variable is used. In line with previous studies (Ahlers et al., 2015; Vismara, 2016), the percentage of equity offered is used for the Equity Offered. This parameter identified the risk taking propensity and indicates the specific equity amount of the company that entrepreneurs offer to the crowd. The last explanatoryvariable is Planning, a typical expression of the proactive capability of the entrepreneurs. In line with prior studies (Fernández-Serrano \& Romero, 2013; Guzmán \& Santos, 2001; Santos-Cumplido \& Liñán, 2007), which used this parameter as a measure of the proactivity in the EO construct, for this variable the main initiatives of the entrepreneurs are considered: business planning activities, detailed long-term plans and other dynamic energizer behaviours (e.g. providing training for their employees and plan enterprise expansion). A dummy variable for the company's planning of activities is used.

\subsubsection{Control Variables}

A number of control variables from the survey are included in both the models. In line with prior studies, this paper also assumes the relevance of the companies' team (Vismara, 2016), thus it incorporates both the entrepreneurs (Ahlers et al., 2015; Vulkan et al., 2016) and the staff (Ahlers et al., 2015; Plummer et al., 2016). Both the variable Founders and Team size, respectively, as a measure of the founding team size and the total company team, are used. For the first of these two control variables, the number of founders is considered, while for the second, the total number of all the members of the team (including both staff and founders) is used.

In this study it is also controlled for firm age, industry, location, company size and platform size. The variable Years is the number of years in which the company has been active since its establishment (Ahlers et al., 2015; Ralcheva \& Roosenboom, 2016). The last following four control variables are measured as dummies, and are: Service Industry, Big City, Start up size and Platform. The industry sector is an important element for the financing of companies (Baum \& Silverman, 2004), therefore it is controlled for possible differences between companies focused on the service industry (one of the most common categories of start ups and SMEs in Italy) and the others sectors. In this study, another important aspect to consider is the location of the initiatives (Hornuf \& Schwienbacher, 2018; Ralcheva \& Roosenboom, 2016; Vismara, 2016), thus a dummy is used in order to distinguish if the company is based in a big city or not. The main target of the ECF mechanism are start ups and SMEs, so a dummy variable is included to measure the company's type. Furthermore, it is controlled for offers launched on big or small platforms (dummy variable), as a measure of the size of the portals (Note 1). Finally, in the first models it is also included the capital collected, i.e. the variable Capital (in $€ 1,000$ ), as a measure of the project size (Ahlers et al., 2015; Lukkarinen et al., 2016). 


\section{Results}

\subsection{Descriptive Statistics}

Table 1 reports the means, standard deviations (SD), minimum (Min) and maximum (Max) values for each variable. The percentage of funding amount ranges from $0 \%$ to $500 \%$ and the average initiatives in the sample raises $146 \%$ of the initial target capital to reach. The average number of investors that finance projects is 54 and this second dependent variable ranges from 0 to 320. The table shows that about the half of companies (precisely $49 \%$ ) decided to create and launch new products/services in the following years, while the $64 \%$ of them made proactive planning initiatives. Equity offered on average is $10.82 \%$ and it ranges from $0.10 \%$ to $50 \%$.

Table 1 provides also descriptive statistics of control variables. The average number of founders is 2.57 , the team size on average is 6.46 and the average capital raised is about $€ 165,750$. Many projects were posted on big platforms (74\%) and the average firm age is just over two and a half years. Companies are mostly start ups (88\%) of service industry $(75 \%)$ and located in big cities $(59 \%)$.

Table 1. Descriptive statistics

\begin{tabular}{llllll}
\hline & Obs & Mean & SD & Min & Max \\
\hline $\begin{array}{l}\text { Dependent variables } \\
\text { Funding Amount (\%) }\end{array}$ & 134 & 145.69 & 122.04 & 0 & 500 \\
No. Investors & 134 & 54.14 & 59.05 & 0 & 320 \\
$\begin{array}{l}\text { Explanatory variables } \\
\text { Innovativeness }\end{array}$ & & & & & \\
Product Innovation & 134 & 0.49 & 0.50 & 0 & 1 \\
Risk Taking & & & & & \\
Equity Offered (\%) & 134 & 10.49 & 9.38 & 0.10 & 50 \\
$\begin{array}{l}\text { Proactiveness } \\
\text { Planning }\end{array}$ & & & & & \\
Control variables & 134 & 0.64 & 0.48 & 0 & 1 \\
Founders & & & & & \\
Team size & 134 & 2.57 & 1.29 & 1 & 8 \\
Years & 134 & 6.46 & 3.84 & 2 & 25 \\
Service Industry & 134 & 2.70 & 3.14 & 0 & 23 \\
Big City & 134 & 0.75 & 0.43 & 0 & 1 \\
Start up Size & 134 & 0.59 & 0.49 & 0 & 1 \\
Platform & 134 & 0.88 & 0.31 & 0 & 1 \\
Capital (in $€ 1,000)$ & 134 & 0.74 & 0.43 & 0 & 1 \\
\hline & 134 & 180.75 & 183.37 & 0 & 1,080 \\
\hline
\end{tabular}

In the analyses it is checked for multicollinearity and heteroskedasticity, and there were no points of concern. Table 2 reports correlations of the variables included in the analyses and the variance inflation factor (VIF) for each parameter. Variance inflation factors present values below the conventional thresholds. No one average VIF exceeded 3 and also no one maximum VIF exceeded 4. Both are below the critical cut-off values, respectively, of 6 and 10). The mean VIF is 1.48 and the maximum 2.03 (see Table 3). Also the correlation matrix presents values lower than the traditional threshold of 0.7 , showing the absence of multicollinearity. 
Table 2. Correlation matrix

\begin{tabular}{|c|c|c|c|c|c|c|c|c|c|c|c|c|c|}
\hline & & 1 & 2 & 3 & 4 & 5 & 6 & 7 & 8 & 9 & 10 & 11 & VIF \\
\hline 1 & Prod. Innov. & 1 & & & & & & & & & & & 1.91 \\
\hline 2 & Equity Off.(\%) & $-0.239 * * *$ & 1 & & & & & & & & & & 1.24 \\
\hline 3 & Planning & $0.611 * * *$ & $-0.236 * * *$ & 1 & & & & & & & & & 1.89 \\
\hline 4 & Founders & -0.022 & $0.182 * *$ & -0.053 & 1 & & & & & & & & 1.07 \\
\hline 5 & Team size & $0.235 * * *$ & $-0.256 * * *$ & $0.273 * * *$ & 0.009 & 1 & & & & & & & 1.35 \\
\hline 6 & Years & $0.184 * *$ & -0.137 & $0.177 * *$ & -0.048 & $0.263 * * *$ & 1 & & & & & & 1.83 \\
\hline 7 & Service Ind. & -0.095 & -0.045 & 0.006 & -0.081 & 0.109 & -0.037 & 1 & & & & & 1.08 \\
\hline 8 & Big City & -0.103 & -0.102 & 0.021 & -0.106 & 0.119 & -0.068 & $0.166^{*}$ & 1 & & & & 1.12 \\
\hline 9 & Start up Size & $-0.171 * *$ & $0.162 *$ & $-0.216^{* *}$ & -0.025 & $-0.421 * * *$ & $-0.631 * * *$ & -0.093 & -0.050 & 1 & & & 2.03 \\
\hline 10 & Platform & 0.059 & -0.087 & $0.208 * *$ & -0.019 & 0.034 & $-0.154 *$ & -0.015 & -0.094 & 0.011 & 1 & & 1.13 \\
\hline 11 & Capital(€1 000) & $0.499 * * *$ & 0.006 & $0.480 * * *$ & 0.029 & $0.253 * * *$ & $0.228 * * *$ & 0.017 & -0.041 & $-0.321 * * *$ & 0.043 & 1 & 1.61 \\
\hline
\end{tabular}

Note. Significance level at $1 \%(* * *), 5 \%(* *)$, and $10 \%\left(^{*}\right)$

\subsection{Regression Analyses}

In this section, evidences of the impact of the three exploratory variables on ECF performance are provided. Table 3 shows the results of regression analyses with dependent variables measuring ECF performance: funding amount (\%), in the model 1, and number of investors, in the model 2.

Respectively an OLS regression is performed in the model 1, while a Poisson regression is performed in the second model. These choices follow the current literature and are appropriate because: the first dependent variable (model 1) is expressed as the final percentage of the amount raised at the end of the campaign; the second dependent variable (model 2) is a count of the final number of investors at the end of ECF campaigns. In the second model (a count model), it is important to underline that there are not excess zeros. In both the models, robust standard errors are used and control variables are included. The evidence supports the three hypotheses, in fact the exploratory variables are statistically significant in both the models.

Firstly, product innovation positively affects the percentage of funding amount (coefficient $=0.350$, significant at $10 \%$ ) and crowd participation, i.e. the number of investors (coefficient $=0.151$, significant at $1 \%$ ).

In accordance with hypothesis 2 , equity offered has a negative impact on the percentage of funding amount (coefficient $=-2.140$, significant at $1 \%$ ) and on the number of investors (coefficient $=-2.518$, significant at $5 \%$ ). In this case, a larger percentage of equity offered is related to a smaller amount of funding collected (model 1) and a smaller crowd participation in number of investors (model 2).

Finally, it is found that planning is associated with a larger percentage of funding amount (coefficient $=0.679$, significant at $1 \%$ ) and positively influences a larger number of investors (coefficient $=1.059$, significant at $1 \%$ ). 
Table 3. Determinants of the success of ECF campaigns: regression results

\begin{tabular}{|c|c|c|c|c|}
\hline & \multicolumn{2}{|c|}{$\begin{array}{l}\text { Model 1: } \\
\text { Funding Amount (\%) }\end{array}$} & \multicolumn{2}{|c|}{$\begin{array}{l}\text { Model 2: } \\
\text { No. Investors } \\
\end{array}$} \\
\hline \multirow{2}{*}{$\begin{array}{l}\text { Explanatory variables } \\
\text { Innovativeness }\end{array}$} & \multirow{4}{*}{0.350} & \multirow{4}{*}{$*$} & \multirow{4}{*}{0.151} & \multirow{4}{*}{$* * *$} \\
\hline & & & & \\
\hline Product Innovation & & & & \\
\hline Risk Taking & & & & \\
\hline Equity Offered (\%) & -2.140 & $* * *$ & -2.518 & $* *$ \\
\hline Proactiveness & & & & \\
\hline Planning & 0.679 & $* * *$ & 1.059 & $* * *$ \\
\hline \multicolumn{5}{|l|}{ Control variables } \\
\hline Founders & 0.009 & & -0.001 & \\
\hline Team size & -0.007 & $*$ & 0.022 & $*$ \\
\hline Years & -0.013 & & -0.017 & \\
\hline Service Industry & 0.115 & & -0.023 & \\
\hline Big City & 0.072 & & 0.094 & \\
\hline Start up Size & 0.104 & & -0.197 & \\
\hline Platform & 0.185 & & 0.834 & $* * *$ \\
\hline Capital (in $€ 1,000$ ) & 0.003 & $* * *$ & & \\
\hline Constant & 0.193 & & 2.260 & $* * *$ \\
\hline No. observation & 134 & & 134 & \\
\hline Maximum VIF & 2.03 & & & \\
\hline Mean VIF & 1.48 & & & \\
\hline Wald $\chi$ sq. & & & 92.33 & \\
\hline (Pseudo) $\mathrm{R}^{2}$ & 0.612 & & 0.417 & \\
\hline
\end{tabular}

Note. Significance level at $1 \%(* * *), 5 \%(* *)$, and $10 \%(*)$.

\section{Discussion and Conclusion}

\subsection{Discussion}

The present contribution explores the importance of entrepreneurship for ECF performance. The study intends to examine how and to what extent entrepreneurship is significant in affecting two main ECF performance outcomes, i.e. funding amount collected and number of investors involved.

In this paper, the presence of new significant drivers in the ECF context is explored and new parameters of the entrepreneurial sphere are empirically analyzed. Put differently, the main goal of this paper is to investigate the role of the three traditional dimensions of EO in the success of ECF campaigns in the Italian case. The assumption is that innovativeness (i.e. product innovation), risk taking (i.e. equity offered) and proactiveness (i.e. planning) can play a signalling role for investors. Thus, this work aims to analyse the impact of these parameters on the success rate of projects in Italy within the framework of information asymmetries and signalling theory.

The number of studies based on the ECF model is limited compared to the reward model. The nascent ECF literature recently started to explore successful drivers and the few previous empirical studies have highlighted a positive effect of several factors on ECF performance. These papers that draw on signalling theory provided insights mainly on the role of networks or media (Block et al., 2018; Lukkarinen et al, 2016; Polzin et al., 2018; Vismara, 2016), education background of the team (Lukkarinen et al. 2016; Ahlers et al., 2015), certifications and equity retention (Ahlers et al., 2015; Ralcheva \& Roosenboom, 2016; Vismara, 2016).

The present study shows new variables perceived as quality signals and provides evidence that entrepreneurship plays a key role in the success of ECF campaigns. The results highlight that the three dimensions of EO sphere are significantly related to ECF performance outcomes. Product innovation and planning are predictors of ECF campaign success and positively influence both funding amount and number of investors.

Product innovation has a positive impact on ECF outcomes, in fact, it helps companies to achieve superior performance in term of funding amount collected and investors involved. Investors perceive this parameter as a signal of the innovative capability of the companies and their efforts in the development of new products/services. Future products/services that companies planned to create and launch, could attract a larger number of investors and higher amount of funding. This is particularly true when these new products/services are 
also offered in ECF campaigns in pre-order or reward forms (Belleflamme et al., 2014).

Also proactive initiatives play an important role in the success of ECF campaigns. In fact, planning activities are a key element for investors' decisions to finance a project. Higher initiatives and activities in this sense represent a valid motivation for investors, which commit financial resources to the project aware of its potential and the future directions or programs.

Equity offered in large percentage negatively affects ECF performance and this suggests that the level of uncertainty is significant for investors in the ECF context (Ahlers et al., 2015; Vismara, 2016). This parameter plays a signalling role for investors as suggested by signalling theory (Leland \& Pyle, 1977) and presents similarities to other financial contexts (e.g. VCs) (Busenitz et al., 2005).

\subsection{Conclusion}

This paper is the first to focus on entrepreneurship in the ECF research stream. In the crowdfunding field, it is present just a contribution of Oo et al. (2018) in the reward-based context, even if it included different parameters. Despite studies on new determinants of ECF success is growing, scholars know very little about how entrepreneurship is relevant for ECF outcomes. This study expands both the literature on entrepreneurship and crowdfunding. Recent trends in the field of entrepreneurship proposed a dynamic view on entrepreneurship (Van Der Zwan et al., 2012) and highlighted that the entrepreneurial process is more than the creation of a new business and it is not complete with the establishment of the venture (Brockner et al., 2004; Cardon et. al, 2005; DeTienne, 2010). In line with this new trend, this study focuses on the capability of companies to raise funds. This work offers a new entrepreneurial framework for understanding the potential role of entrepreneurship in the funding success, one of the key aspects of the entrepreneurial process after the venture creation.

The contribution of this study is manifold. The framework developed here summarizes some important factors of past studies in the entrepreneurship field belonging to the EO sphere. It also offers orientation and guidance for future empirical research as well as key concepts to build on. Hopefully, this study could contribute to the current debate on the role of entrepreneurial attributes in the entrepreneurial process, and - in a more specific way - the impact on the fundraising performance.

This paper also expands the current literature on ECF, including different variables and an original construct. The findings of the present study disclose that innovativeness, risk taking and proactiveness are strategic elements in the ECF context. This study highlights the importance of entrepreneurship also in the ECF field, in fact these three dimensions of EO represents significant determinants of ECF performance.

\subsection{Implications}

The ECF market presents a challenging environment for investors to evaluate the value of new ventures. Before investors finance a project, they must evaluate a series of parameters that meet their goals. Some information, that could be useful to them, often are embedded in the capabilities of the entrepreneurs (Alvarez \& Busenitz, 2001) or sometimes are not well exposed in ECF online campaigns. This paper highlights information in the entrepreneurial sphere perceived as quality signals by investors, providing valid information for platform managers, investors and entrepreneurs in launching ECF campaigns. Moreover, this work can provide support to policy makers, who promote new types of fundraising to support new ventures or entrepreneurs and make decisions on financial tools. Policy makers, in particular authorities and governments, should encourage entrepreneurs to pay more attention to the planning, the amount of equity offered and to the introduction of new innovative products, thus to improve their innovation efforts.

In this virtual context, a significant challenge facing entrepreneurs is to communicate their knowledge about the new venture. The findings have several implications for entrepreneurs (that propose initiatives) and platform managers (that publish projects on their online portal). Both types of actors should acknowledge the importance of signals and should implement actions in order to improve the quality of the campaigns. Platform managers should reserve specific spaces of the campaign window for providing further details (e.g. description of the plans, future activities, product innovations, technologies) and improve current project spaces with more specific sections. ECF platforms act as intermediaries between entrepreneurs and investors, thus their managers should facilitate the flow of information, in particular of some key elements such as the innovative or planning activities of the companies and the status of the shareholders.

Entrepreneurs should implement both planning (through more proactive initiatives) and product innovation (through the introduction of new products/services), and should reflect on the negative effect of a large amount of equity offered when they decide to sell equity shares. Furthermore, they should introduce specific details in a clear way - e.g. by providing ad hoc documents or enriching descriptions in the company profile (also in their 
social networks or company websites) - about company development and its future perspectives, especially in terms of future plans, strategies and new innovative products.

Investors are interested in the future developments of the company in which they invest, becoming shareholders. They pay great attention to the future activities that companies have planned and to future innovative actions. Furthermore, investors are particularly vigilant about the state of both entrepreneurs and the shareholders.

The three parameters analysed in this paper represent observable signals for investors and can reduce the uncertainty associated with the initiative, limiting the information asymmetry problem.

\subsection{Limitations and Further Research}

This paper has some limitations that need to be underlined and offers opportunities for further research. First, the study focuses on three aspects related to the entrepreneurship literature, but other possible factors, such as market conditions and the capabilities of the start ups or SMEs, are not included. Considering the EO construct, some parameters already used in entrepreneurship literature are used and contextualized to the field of ECF (e.g. equity offered). However, it is not possible to exclude that there may be other parameters that can be used for the same purpose.

Second, the decision-making process of investors in the crowdfunding context, typically small and less sophisticated (Belleflamme et al., 2014), is a new challenge. So what effectively lead to successful fundraising for new ventures is an evolving topic and attract great interest among scholars and practitioners. Furthermore, it is important to consider that sometimes investors could be influenced by parameters that are difficult to measure. Both personal motivations (e.g. factors of non-monetary nature) and the 'lottery effect' might be included in this type of factor that can affect the investors' decision to finance a project and the amount invested.

Third, there is a lack of studies that explore the role of entrepreneurship in the ECF research stream. The absence of other empirical cases that examined the impact of entrepreneurial aspects in ECF performance does not allow comparison with other countries. Finally, this work analysed only one country, with a specific regulation. However, this could be an opportunity to replicate the study in other countries and to compare differences.

The findings of this study are novel and could represent a basis for further research. The measurement of ECF performance and the successful driver of campaigns are topics of considerable discussion in the literature. Starting from this paper, the next study could extend the concept of EO and introduce new parameters. Moreover, it will be possible to enlarge the sample and enrich the analyses with further performance measures. Finally, another possible stage of this study is to adopt the framework in other fundraising platforms (e.g. P2P lending or other crowdfunding models) and in other types of financing (e.g. venture capitalists or business angels).

\section{References}

Ahlers, G. K., Cumming, D., Gunther, C., \& Schweizer, D. (2015). Signaling in Equity Crowdfunding. Entrepreneurship Theory and Practice,39(4), 955-980. https://doi.org/10.1111/etap.12157

Akerlof, G. A. (1970). The market for 'lemons': quality uncertainty and the market mechanism. The Quarterly Journal of Economics, 84(3), 488-500. https://doi.org/10.2307/1879431

Alvarez, S., \& Busenitz, L. W. (2001). The entrepreneurship of resource-based theory. Journal of Management, 27(6), 755-775. http://dx.doi.org/10.1177/014920630102700609

Baird, I.S., \& Thomas, H. (1985). Toward a contingency model of strategic risk taking. Academy of Management Review, 10(2), 230-243. http://dx.doi.org/10.2307/257965

Baum, J. A. C., \& Silverman, B. S. (2004). Picking winners or building them? Alliance, intellectual, and human capital as selection criteria in venture financing and performance of biotechnology start-ups. Journal of Business Venturing, 19(3), 411-436. https://doi.org/10.1016/S0883-9026(03)00038-7

Belleflamme, P., Lambert, T., \& Schwienbacher, A. (2014). Crowdfunding: tapping the right crowd. Journal of Business Venturing, 29(5), 585-609. https://doi.org/10.1016/j.jbusvent.2013.07.003

Block, J. H., Hornuf, L., \& Moritz, A. (2018). Which updates during an equity crowdfunding campaign increase crowd participation? Small Business Economics, 50(1), 3-27. https://doi.org/10.1007/s11187-017-9876-4

Block, Z., \& MacMillan, I. C. (1985). Milestones for successful venture planning. Harvard Business Review, 63(5), 184-196.

Brockner, J., Higgins, E. T., \& Low, M. B. (2004). Regulatory focus theory and the entrepreneurial process. Journal of Business Venturing, 19(2), 203-220. https://doi.org/10.1016/S0883-9026(03)00007-7 
Bruton, G. D., \& Rubanik, Y. (2002). Resources of the Firm, Russian High-Technology Startups, and Firm Growth. Journal of Business Venturing, 17(6), 553-576. https://doi.org/10.1016/S0883-9026(01)00079-9

Busenitz, L.W., Fiet, J.O., \& Moesel, D. D. (2005). Signaling in Venture Capitalist-New Venture Team Funding Decisions: Does it Indicate Long-Term Venture Outcomes? Entrepreneurship Theory and Practice.29(1), 1-12. https://doi.org/10.1111/j.1540-6520.2005.00066.x

Bygrave, W. D. (2004). The entrepreneurial process. In W.D. Bygrave \& A. Zacharakis (Eds.).The portable MBA in entrepreneurship. Hoboken, NJ: John Wiley \& Sons, 1-28.

Cardon, M. S., Zietsma, C., Saparito, P., Matherne, B. P., \& Davis, C. (2005). A tale of passion: new insights into entrepreneurship from a parenthood metaphor. Journal of Business Venturing, 20(1), 23-45. https://doi.org/10.1016/j.jbusvent.2004.01.002

Carter, N. M., Gartner, W. B., \& Reynolds, P. D. (1996). Exploring start-up event sequences. Journal of Business Venturing, 11(3), 151-166. http://dx.doi.org/10.1016/0883-9026(95)00129-8

Chen, J., Zhu, Z., \& Xie, H. (2004). Measuring intellectual capital: A new model and empirical study. Journal of Intellectual Capital, 5(1), 195-212.https://doi.org/10.1108/14691930410513003

Cholakova, M., \& Clarysse, B. (2015). Does the possibility to make equity investments in crowdfunding projects crowd out reward-based investments? Entrepreneurship Theory and Practice, 39(1), 145-172. https://doi.org/10.1111/etap.12139

Colombo, M., Cumming, D. J., \& Vismara, S. (2016). Governmental venture capital for innovative young firms. Journal of Technology Transfer, 41(1), 10-24. https://doi.org/10.1007/s10961-014-9380-9

Cooper, A. C. (1973). Technical Entrepreneurship: What do We Know? Research and Development Management, 3(2), 59-64. https://doi.org/10.1111/j.1467-9310.1973.tb01002.x

Covin, J. G., \& Miles, M. P. (1999). Corporate Entrepreneurship and the Pursuit of Competitive Advantage. Corporate Entrepreneurship and Growth, 23(3), 47-63. https://doi.org/10.1177/104225879902300304

Covin, J. G., \& Slevin, D. P. (1989). Strategic management of small firms in hostile and benign environments. Strategic Management Journal, 10(1), 75-87. https://doi.org/10.1002/smj.4250100107

Covin, J. G., \& Slevin, D. P. (1991). A conceptual model of entrepreneurship as firm behaviour. Entrepreneurship: Theory and Practice, 16(1), 7-24. https://doi.org/10.1177/104225879101600102

Cunneen, G. J., \& Mankelow, D. J. (2007). Towards a Process Model of Independent Growth Firm Creation. Small Enterprise Research, 15(1), 90-105. https://doi.org/10.1080/13215906.2007.11005834

Deeds, D. L., Decarolis, D., \& Coombs, J. E. (1997). The impact of firm specific capabilities on the amount of capital raised in an initial public offering: Evidence from the biotechnology industry. Journal of Business Venturing, 12(1), 31-46. https://doi.org/10.1016/S0883-9026(97)84970-1

DeTienne, D. R. (2010). Entrepreneurial exit as a critical component of the entrepreneurial process: Theoretical development. Journal of Business Venturing, 25(2), 203-215. https://doi.org/10.1016/j.jbusvent.2008.05.004

Eisenhardt, K. M., \& Schoonhoven, C. B. (1990). Organizational growth: Linking founding team, strategy, environment, and growth among U.S. semiconductor ventures 1978-1988. Administrative Science Quarterly, 35, 504-529. https://doi.org/10.2307/2393315

Fernández-Serrano, J., \& Romero, I. (2013). Entrepreneurial quality and regional development: Characterizing SME sectors in low income areas. Papers in Regional Science, 92(3), 495-513. https://doi.org/10.1111/j.1435-5957.2012.00421.x

Guzmán, J., \& Santos, F. J. (2001). The booster function and the entrepreneurial quality: An application to the province of Seville. Entrepreneurship \& Regional Development: An International Journal, 13(3), 221-228. https://doi.org/10.1080/08985620110035651

Hornuf, L., \& Schwienbacher, A. (2018). Market mechanisms and funding dynamics in equity crowdfunding. Journal of Corporate Finance, 50(C), 556-574. https://doi.org/10.1016/j.jcorpfin.2017.08.009

Huang, C. J., \& Liu, C. J. (2005). Exploration for the relationship between innovation, IT and performance. Journal of Intellectual Capital, 6(2), 237-252. https://doi.org/10.1108/14691930510592825

Kessler, A., \& Frank, H. (2009). Nascent entrepreneurship in a longitudinal perspective the impact of person, environment, resources and the founding process on the decision to start business activities. International Small Business Journal, 27(6), 720-742. https://doi.org/10.1177/0266242609344363 
Kets de Vries, M. F. R. (1977). The Entrepreneurial Personality: A Person at the Crossroads. Journal of Management Studies, 14(1), 34-57. https://doi.org/10.1111/j.1467-6486.1977.tb00616.x

Kortum, S., \& Lerner, J. (2000). Assessing the contribution of venture capital to innovation. TheRAND Journal of Economics, 31(4), 674-692.https://doi.org/10.2307/2696354

Korunka, C., Frank, H., Lueger, M., \& Mugler, J. (2003). The entrepreneurial personality in the context of resources, environment, and the startup process-a configurational approach. Entrepreneurship Theory and Practice, 28(1), 23-42. https://doi.org/10.1111/1540-8520.00030

Lee, C., Lee, K., \& Pennings, J. (2001). Internal Capabilities, External Networks, and Performance: A Study on Technology-Based Ventures. Strategic Management Journal, 22(6-7), 615-640. https://doi.org/10.1002/smj.181

Leland, H. E., \& Pyle, D. H. (1977). Informational asymmetries, financial structure, and financial intermediation. Journal of Finance, 32(2), 371-387. https://doi.org/10.2307/2326770

Lepak, D. P., Bartol, K. M., \& Erhardt, N. L. (2005). A contingency framework for the delivery of HR practices. Human Resource Management Review, 15(2), 139-159. https://doi.org/10.1016/j.hrmr.2005.06.001

Leyden, D. P., \& Link, A. N. (2015). Toward a theory of the entrepreneurial process. Small Business Economics, 44(3), 475-484. https://doi.org/10.1007/s11187-014-9606-0

Li, H., \& Atuahene-Gima, K. (2001). Product innovation strategy and the performance of new technology ventures in China. The Academy of Management Journal, 44(6), 1123-1134. https://doi.org/10.5465/3069392

Lukkarinen, A. Teich, J. E, Wallenius H., \& Wallenius, J. (2017). Success Drivers of Online Equity Crowdfunding Campaigns.Decision Support $\quad$ Systems, $\quad 87(\mathrm{C}), \quad 26-38$. https://doi.org/10.1016/j.dss.2016.04.006

Lumpkin, G. T., \& Dess, G. G. (1996). Clarifying the entrepreneurial orientation construct and linking it to performance. Academy of Management Review, 21(1), 135-173. https://doi.org/10.5465/amr.1996.9602161568

McCann, J. E. (1991). Patterns of growth, competitive technology, and financial strategies in young ventures. Journal of Business Venturing, 6(3), 189-208. https://doi.org/10.1016/0883-9026(91)90009-3

Miller, D. (1983). The correlates of entrepreneurship in three types of firms. Management Science, 29(7), 770-791. https://doi.org/10.1287/mnsc.29.7.770

Miller, D. (1987). Strategy making and structure: Analysis and implications for performance. Academy of Management Journal, 30(1), 7-32. https://doi.org/10.5465/255893

Miller, D., \& Friesen, P. H. (1978). Archetypes of strategy formulation.Management Science, 24(9), 921-933. https://doi.org/10.1287/mnsc.24.9.921

Miller, D., \& Friesen, P. H. (1982). Innovation in conservative and entrepreneurial firms: Two models of strategic momentum. Strategic Management Journal, 3(1), 1-25. https://doi.org/10.1002/smj.4250030102

Mochkabadi, K., \& Volkmann, C. K. (2018). Equity crowdfunding: a systematic review of the literature. Small Business Economics, 1-44. https://doi.org/10.1007/s11187-018-0081-x

Moroz, P. W., \& Hindle, K. (2012). Entrepreneurship as a process: Toward harmonizing multiple perspectives. Entrepreneurship Theory and Practice, 36(4), 781-818. https://doi.org/10.1111/j.1540-6520.2011.00452.x

Nadeau, P. (2010). Venture capital investment selection: Do patents attract investors? Strategic Change, 19(7-8), 325-342. https://doi.org/10.1002/jsc.879

Oo, P. P., Allison, T. H., Sahaym, A., \& Juasrikul, S. (2018). User entrepreneurs' multiple identities and crowdfunding performance: Effects through product innovativeness, perceived passion, and need similarity. Journal of Business Venturing, (in press). https://doi.org/10.1016/j.jbusvent.2018.08.005

Ordanini, A., Miceli, L., Pizzetti, M., \& Parasuraman, A. (2011). Crowd-funding: Transforming customers into investors through innovative service platforms. Journal of Service Management, 22(4), 443-470.https://doi.org/10.1108/09564231111155079

Plummer, L., Allison, T., \& Connelly, B. (2015). Better Together? Signaling Interactions in New Venture Pursuit of Initial External Capital. Academy of Management Journal, 59(5), 1585-1604. https://doi.org/10.5465/amj.2013.0100 
Politecnico of Milan - School of Management. (2018). 3 Report italiano sul CrowdInvesting, Osservatori Entrepreneurship \& Finance.

Polzin, F.,Toxopeus, H., \& Stam, E. (2018). The wisdom of the crowd in funding.Information heterogeneity and social networks of crowdfunders. Small Business Economics, 50(2), 251-273. https://doi.org/10.1007/s11187-016-9829-3

Quinn, J. B. (1979). Technological innovation, entrepreneurship, and strategy. Sloan Management Review, 20(3), 19-30. https://doi.org/10.1109/EMR.1983.4306000

Ralcheva, A., \& Roosenboom, P. (2016). On the Road to Success in Equity Crowdfunding, working paper, http://dx.doi.org/10.2139/ssrn.2727742

Reynolds, P. D. (2007). New firm creation in the United States: A PSED I overview. Foundations and Trends in Entrepreneurship, 3(1), 1-150. http://dx.doi.org/10.1561/0300000010

Santos-Cumplido, F. J., \& Liñán, F. (2007). Measuring entrepreneurial quality in Southern Europe. International Entrepreneurship and Management Journal, 3(1), 87-107. https://doi.org/10.1007/s11365-006-0015-y

Schumpeter, J.A. (1947). The creative response in economic history. Journal of Economic History, 7, 149-159. https://doi.org/10.1017/S0022050700054279

Shane, S., \& Cable, D. (2002). Network Ties, Reputation, and the Financing of New Ventures. Management Science, 48(3), 364-381. https://doi.org/10.1287/mnsc.48.3.364.7731

Shane, S., \& Venkataraman, S. (2000). The promise of entrepreneurship as a field of research. Academy of Management Review, 25(1), 217-226. https://doi.org/10.5465/amr.2000.2791611

Smith, K. G., Collins, C. J., \& Clark, K. D. (2005). Existing knowledge, knowledge creation capability, and the rate of new product introduction in high-technology firms. The Academy of Management Journal, 48(2), 346-357. https://doi.org/10.5465/amj.2005.16928421

Spence, M. (1973). Job Market Signaling. Quarterly Journal of Economics, 87(3), 355-374. https://doi.org/10.2307/1882010

Stevenson, H. H., \& Jarillo, J. C. (1990). A paradigm of entrepreneurship: Entrepreneurial management. Strategic Management Journal, 11(5), 17-27. https://doi.org/10.1007/978-3-540-48543-8_7

Van Der Zwan, P., Verheul, I., \& Thurik, R. (2012). The entrepreneurial ladder, and regional development. Small Business Economics, 39(3), 627-643. https://doi.org/10.1007/s11187-011-9334-7

Vesper, K. H., \& Holmdahl, T. G. (1973). How venture management fares in innovative companies. Research Management, 16(3), 30-33. https://doi.org/10.1080/00345334.1973.11756185

Vismara, S. (2018). Information Cascades Among Investors in Equity Crowdfunding. Entrepreneurship Theory and Practice, 42(3), 467-497. https://doi.org/10.1111/etap.12261

Vismara, S. (2016). Equity retention and social network theory in equity crowdfunding. Small Business Economics, 46(4), 579-590. https://doi.org/10.1007/s11187-016-9710-4

Vulkan, N., Åstebro, T.B., \& Sierra, M.F. (2016), Equity Crowdfunding: A New Phenomena. Journal of Business Venturing Insights, 5, 37-49. https://doi.org/10.1016/j.jbvi.2016.02.001

Webb, J.W., Kistruck, G., Ireland, R. D., \& Ketchen, D. J. (2010). The Entrepreneurship Process in Base of the Pyramid Markets: The Case of Multinational Enterprise/Nongovernment Organization Alliances. Entrepreneurship Theory and Practice, 34(3), 555-581. https://doi.org/10.1111/j.1540-6520.2009.00349.x

Wiklund, J. (1999). The sustainability of the entrepreneurial orientation-performance relationship. Entrepreneurship Theory and Practice, 24(1), 37-49. https://doi.org/10.1177/104225879902400103

Zahra, S. A. (1991). Predictors and financial outcomes of corporate entrepreneurship: an exploratory study. Journal of Business Venturing, 6(4), 259-285. https://doi.org/10.1016/0883-9026(91)90019-A

Zahra, S. A., \& Covin, J. (1993). Business Strategy, Technology Policy and Company Performance. Strategic Management Journal, 14(6), 451-478. https://doi.org/10.1002/smj.4250140605

Zheng, H., Li, D., Wua, J., \& Xu, Y. (2014). The role of multidimensional social capital in crowdfunding: A comparative study in China and US. Information \& Management, 51(4), 488-496. https://doi.org/10.1016/j.im.2014.03.003

Zirger, B. J., \& Maidique, M. A. (1990). A model of newproduct development: An empirical test. Management 
Science, 36(7), 867-883. https://doi.org/10.1287/mnsc.36.7.867

\section{Note}

Note 1. This work considers a portal as big if it has published at least 28 projects since its establishment (until the date of June 2018, which is our sampling period). Three platforms launched over 28 projects (Crowd Fund Me, Mamacrowd and 200crowd), while the others fewer than 15 projects.

\section{Copyrights}

Copyright for this article is retained by the author(s), with first publication rights granted to the journal.

This is an open-access article distributed under the terms and conditions of the Creative Commons Attribution license (http://creativecommons.org/licenses/by/4.0/). 